\title{
PENGARUH MOTIVASI BELAJAR DAN DISIPLIN BELAJAR TERHADAP PRESTASI BELAJAR EKONOMI
}

\author{
Muammar Rinaldi ${ }^{1}{ }^{*}$ \\ 1) Program Studi S1 Pendidikan Ekonomi, Universitas Negeri Medan \\ E-mail: muammarrinaldi@gmail.com
}

\begin{abstract}
Abstrak
Penelitian ini bertujuan untuk (1) mengetahui pengaruh motivasi belajar terhadap prestasi belajar siswa, (2) mengetahui pengaruh disiplin belajar terhadap prestasi belajar siswa, (3) mengetahui besarnya pengaruh motivasi belajar dan disiplin belajar dalam menunjang prestasi belajar ekonomi siswa kelas XI SMAN 1 Babalan Tahun Pembelajaran 2014/2015. Populasi dalam penelitian ini adalah seluruh siswa kelas XI SMAN 1 Babalan yang berjumlah 79 orang. Sampel dalam penelitian ini diambil menggunakan teknik total sampling, yaitu mengambil seluruh populasi sebagai sampel penelitian, yaitu berjumlah 79 orang. Teknik pengumpulan data yang digunakan adalah, dokumentasi dan angket/kuesioner. Teknik analisis data yang digunakan adalah teknik analisis regresi linier berganda dan menggunakan uji hopotesis secara parsial (uji t) dan secara simultan (uji f) serta menggunakan koefisien determinasi. Sebelum dilakukan uji analisis maka dilakukan uji prasyarat analisis yaitu uji normalitas dengan kolmogorov smirnov, uji multikolinieritas, dan uji linieritas. Hasil penelitian menunjukkan bahwa kecenderungan prestasi belajar siswa kelas XI SMAN 1 Babalan dalam kategori cukup. Pengujian terhadap hipotesis secara parsial dengan taraf signifikan 5\%, untuk variabel motivasi belajar (X1) menunjukkan nilai thitung sebesar 1,090 dan nilai ttabel sebesar 1,991 maka diperoleh thitung < ttabel $(1,090<1,991)$ maka Ha ditolak Ho diterima, untuk variabel disiplin belajar (X2) menunjukkan nilai thitung sebesar 4,062 dan nilai ttabel sebesar 1,991 maka diperoleh thitung > ttabel $(4,062>1,991)$ maka Ho ditolak dan Ha diterima.. Pengujian hipotesis secara simultan dengan taraf signifikan 5\% menunjukkan nilai fhitung sebesar 15,743 dan nilai ftabel sebesar 3,12 maka diperoleh fhitung > ftabel $(15,743>3,12)$ maka Ho ditolak Ha diterima, dan koefisien determinasi (adjusted $\mathrm{R}$ square) sebesar 0,450 atau $45 \%$, dimana hal ini menunjukkan bahwa besarnya sumbangan pengaruh yang diberikan oleh variabel motivasi belajar dan disiplin belajar terhadap prestasi belajar adalah sebesar $45 \%$. Berdasarkan hasil analisis data dapat disimpulkan sebagai berikut : 1 . Tidak ada pengaruh positifdan signifikan antara motivasi belajar terhadap prestasi belajar siswa. 2. Ada pengaruh positif dan signifikan antara disiplin belajar terhadap prestasi belajar siswa. 3. Ada pengaruh yang positif dan signifikan antara motivasi belajar dan disiplin belajar secara bersama-sama terhadap prestasi belajar siswa kelas XI SMAN 1 Babalan.
\end{abstract}

\section{Kata Kunci : Motivasi Belajar, Disiplin Belajar, Prestasi Belajar}




\section{PENDAHULUAN}

Peran lembaga pendidikan sangat penting guna menyokong dan membantu terbentuknya sumber daya manusia yang potensial. Pendidikan melalui lembaga formal merupakan cara yang sangat tepat untuk meningkatkan kualitas pembelajaran yang dilakukan oleh guru. Dengan melalui pendidikan, maka tujuan pembangunan yang berorientasi terhadap peningkatan sumber daya manusia yang berkualitas (human quality of resources) dapat dicapai.

Sumber daya manusia sangat diperlukan sebagai modal dasar pembangunan nasional, terutama dalam menghadapi persaingan di zaman globalisasi seperti sekarang ini. Adanya kemajuan ilmu pengetahuan dan teknologi mengakibatkan terjadinya perubahan dan pengembangan masyarakat, yang melahirkan masalah sosial yang lebih kompleks. Adapun upaya untuk menjawab tantangan dan memecahkan masalah tersebut ialah melalui pendidikan, karena peran pendidikan sangat penting untuk menciptakan masyarakat yang cerdas, damai, terbuka dan demokratis.

Secara sederhana pendidikan dapat diartikan sebagai proses kegiatan belajar mengajar di kelas. Proses belajar mengajar merupakan proses paling mendasar dalam aktivitas pendidikan di sekolah, berupa interaksi antara guru dan siswa, guna mencapai tujuan pembelajaran. Keberhasilan belajar siswa dapat dilihat dari kemampuannya dalam menguasai materi pelajaran, prestasi belajar yang dicapai siswa, serta keterampilan siswa. Dengan memperhatikan prestasi belajar siswa, maka dapat diketahui sejauh mana kemampuan dan kualitas siswa.

Guru sebagai pendidik yang berhubungan langsung dengan anak didik harus ikut serta dalam memperhatikan dan bertanggungjawab atas peningkatan prestasi belajar siswa. Tapi usaha guru untuk memotivasi siswa, khususnya motivasi belajar dalam mata pelajaran ekonomi masih belum optimal. Karena masih banyak siswa yang menganggap bahwa ekonomi adalah mata pelajaran yang kurang menarik. Sehingga siswa kurang termotivasi untuk membaca buku mata pelajaran ekonomi. Jadi tugas guru bagaimana mendorong para siswa agar pada dirinya tumbuh motivasi.

Salah satu faktor internal yang mempengaruhi prestasi belajar siswa adalah motivasi. Seseorang yang memiliki motivasi mempunyai kecenderungan untuk mencurahkan segala kemampuannya demi mendapatkan prestasi belajar yang optimal sesuai dengan tujuan yang diharapkan.

Semakin tinggi motivasi yang dimiliki siswa akan mendorong siswa tersebut belajar lebih giat lagi, dengan demikian frekuensi
NIAGAWAN Vol 8 No 3 November 2019

belajarnya menjadi semakin meningkat, sehingga prestasi belajarnya pun meningkat pula. Siswa yang menyelesaikan tugas belajar dengan perasaan termotivasi terhadap materi yang telah dipelajari, akan lebih mungkin memahami pelajaran baik secara teori maupun praktis materi yang telah di pelajari.

Untuk memperoleh prestasi belajar yang baik, selain dengan motivasi belajar yang tidak kalah pentingnya adalah pendidikan disiplin siswa. Siswa yang mempunyai motivasi yang kuat akan diikuti dengan disiplin diri, dimana disiplin tersebut merupakan sesuatu yang berkenaan dengan pengendalian diri seseorang terhadap bentuk-bentuk aturan. Berhasil atau gagalnya dalam membangkitkan dan mendayagunakan motivasi dalam proses pembelajaran berkaitan dengan upaya pembinaan kedisiplinan diri. Didalam pengelolaan pengajaran, disiplin merupakan suatu cara untuk melatih siswa agar belajar tepat waktu, dan mengelola kegiatannya dengan menjaga disiplin belajar dalam proses pembelajaran di sekolah. Tanpa adanya kesadaran dan keharusan melaksanakan aturan yang sudah ditentukan sebelumnya, pengajaran tidak mungkin mencapai target yang maksimal.

Berdasarkan studi dokumen yang dilakukan oleh penulis di SMA Negeri 1 Babalan diperoleh keterangan bahwa prestasi belajar Ekonomi di kelas XI kurang memuaskan, dapat dilihat pada daftar kumpulan nilai ekonomi yang diketahui bahwa nilai rata-rata peserta didik masih rendah karena berada dibawah nilai Kriteria Ketuntasan Minimum (KKM) yang ditentukan oleh sekolah pada mata pelajaran ekonomi di SMAN 1 Babalan adalah 75. Pada setiap kelas terdapat banyak siswa yang tidak mencapai Kriteria Ketuntasan Minimum (KKM), seperti kelas XI IIS 1 sebanyak 56,52\% atau 23 dari 41 siswa dan kelas XI IIS 2 sebanyak $66,67 \%$ atau 24 siswa dari 38 siswa yang tidak mencapai KKM.

Dari data tersebut sangat jelas bahwa prestasi belajar siswa pada mata pelajaran ekonomi termasuk pada kategori rendah. Hal ini menjadi suatu masalah yang perlu dikaji secara seksama, karena masih banyak siswa yang belum dapat memenuhi nilai yang diharapkan pada mata pelajaran ekonomi.

Kemudian dari hasil pengamatan awal peneliti melihat ada beberapa sikap siswa SMAN 1 Babalan yang memiliki motivasi dan disiplin yang rendah. Dari sudut motivasi, yaitu rendahnya motivasi belajar yang dimiliki siswa SMAN 1 Babalan ditunjukkan dengan masih terdapat siswa yang kurang antusias dalam belajar dan mengerjakan soal ulangan yang diberikan guru. Siswa juga cenderung bercerita dengan teman pada saat guru menjelaskan materi dan tidak mau mengajukan pertanyaan tentang materi yang belum jelas. Kondisi ini terkadang menjadikan siswa enggan untuk belajar, 
merasakan kejenuhan dan keinginan agar proses belajar mengajar cepat selesai.

Dari sudut disiplin belajar, yaitu kurangnya disiplin belajar yang dimiliki siswa SMAN 1 Babalan ditunjukkan dengan masih ada siswa yang terlambat dalam mengikuti pelajaran, selalu terlambat untuk mengumpulkan tugas, siswa juga ada yang keluar masuk ruangan pada saat guru memberikan pelajaran dan siswa juga lebih sering tidak masuk kelas dalam proses pembelajaran.

Selain itu pada saat pembelajaran berlangsung, siswa tidak bersemangat dalam mengikuti dan mendengarkan penjelasan dari guru. Siswa cenderung terlihat bermalasmalasan selama mengikuti pembelajaran. Hal ini mengindikasikan rendahnya motivasi belajar dan disiplin belajar siswa di SMA Negeri 1 Babalan.

\section{TINJAUAN PUSTAKA}

\section{Motivasi Belajar}

Sardiman (2011:73) menyatakan

"Berawal dari kata 'motif' yang diartikan sebagai daya upaya yang mendorong seseorang untuk melakukan sesuatu, maka motivasi dapat diartikan sebagai daya penggerak yang telah menjadi aktif'. Motif menjadi aktif pada saatsaat tertentu, terutama bila kebutuhan untuk mencapai tujuan sangat dirasakan. Sardiman (2011:75) juga mengembangkan pengertian motivasi secara lebih luas bahwa "Motivasi adalah serangkaian usaha untuk menyediakan kondisi-kondisi tertentu, sehingga seseorang mau dan ingin melakukan sesuatu, dan bila ia tidak suka, maka akan berusaha untuk meniadakan atau mengelakkan perasaan tidak suka itu".

Jadi motivasi belajar adalah kondisi psikologis yang mendorong siswa untuk belajar dengan senang dan belajar secara sungguhsungguh, yang pada gilirannya akan terbentuk cara belajar siswa yang sistematis, penuh konsentrasi dan dapat menyeleksi kegiatankegiatannya. Apabila tidak ada motivasi belajar dalam diri siswa, maka akan timbul rasa malas, baik dalam mengikuti proses belajar mengajar maupun mengerjakan tugas-tugas individu dari guru.

Motivasi mempunyai fungsi yang sangat penting dalam belajar siswa, karena motivasi akan menentukan intensitas usaha belajar yang dilakukan oleh siswa. Untuk dapat menghasilkan motivasi yang baik terhadap siswa maka dibutuhkan fungsi motivasi yang utama yaitu
NIAGAWAN Vol 8 No 3 November 2019 sebagai pendorong agar usaha belajar yang dilakukan siswa menjadi lebih meningkat.

Dengan kata lain, dengan melakukan usaha yang tekun, bersungguh-sungguh, dan didasari dengan adanya motivasi, maka seseorang yang belajar itu akan mendapat prestasi belajar yang bagus. Dalam proses belajar mengajar tersebut diperlukan suatu upaya yang dapat meningkatkan motivasi siswa, sehingga siswa yang bersangkutan dapat mencapai prestasi belajar yang optimal.

\section{Disiplin Belajar}

Menurut Gie (dalam Wiyani 2013:159) menyatakan bahwa "disiplin sebagai suatu keadaan tertib yang mana orang-orang yang tergabung dalam suatu organisasi tunduk pada peraturan-peraturan yang telah ada dengan senang hati”.

Selanjutnya Wiyani (dalam Gusnita, 2014:9) dikemukakan bahwa "Disiplin adalah perilaku yang mencerminkan kepatuhan terhadap berbagai nilai yang disepakati oleh semua, baik oleh peserta didik sendiri maupun oleh guru yang tertuang dalam tata tertib atau aturan kelas". Priyodarminto (dalam Rusmiasih, 2013:190) kedisplinan didefinisikan "sebagai kondisi yang tercipta dan terbentuk melalui proses dari serangkaian perilaku yang menunjukkan nilai-nilai ketaatan, kepatuhan, keteraturan, dan ketertiban".

Berdasarkan pendapat para ahli di atas bahwa disiplin itu menuntut individu untuk mengikuti semua peraturan-peraturan dan tata tertib yang berlaku, memiliki pengendalian diri terhadap keteraturan yang berlaku sebagai suatu pola tingkah laku yang diatur sedemikian rupa dimana tanpa paksaan dari orang lain atau dilakukan secara ikhlas dalam melaksanakan dan melakukan tugas oleh karena disiplin menjadi salah satu faktor dalam kehidupan.

Disiplin sangat penting dan dibutuhkan oleh setiap siswa. Disiplin yang tumbuh secara sadar akan membentuk sikap, perilaku, dan tata kehidupan yang teratur yang akan menjadikan siswa sukses dalam belajar. Disiplin akan mengarahkan siswa untuk menjadi pribadi yang bertanggung jawab terhadap hal-hal yang sedang dijalaninya.

\section{METODE PENELITIAN}

Sesuai dengan judul penelitian, maka yang menjadi lokasi penelitian adalah SMA Negeri 1 Babalan Jalan Melati No. 2 P.Berandan pada semester genap T.A 2014/2015. 
Adapun yang menjadi populasi dalam penelitian adalah seluruh siswa kelas XI SMA Negeri 1 Babalan T.A 2014/2015 yang terdiri dari 2 kelas yang berjumlah 79 siswa. peneliti mengambil keseluruhan populasi sebagai sampel. Dengan demikian sampel penelitian adalah sebanyak 79 siswa yang terdiri dari 2 kelas, yaitu kelas XI IIS 1 sebanyak 41 siswa dan kelas XI IIS 2 sebanyak 38 siswa.

Pengumpulan data dalam penelitian ini menggunakan teknik studi dokumen digunakan untuk memperoleh data mengenai nilai mata pelajaran ekonomi siswa kelas XI di SMA Negeri 1 Babalan T.P.2014/2015. Dan metode angket yang digunakan untuk memperoleh data primer mengenai motivasi belajar dan disiplin belajar siswa kelas XI di SMA Negeri 1 Babalan T.P.2014/2015.

Instrumen dalam penelitian ini menggunakan angket dengan model check list dengan skala likert, dimana reponden tinggal membubuhkan tanda rumpun $(\sqrt{ })$ pada kolom jawaban yang terdiri dari 5 skala yang sesuai dengan kondisi yang dihadapi atau dialami oleh responden.

Uji validitas angket menggunakan teknik Korelasi Product Moment. Reliabilitas tes diuji dengan menggunakan rumus Alpha Cronbach. Teknik analisis data yang digunakan adalah regresi linear berganda, uji determinasi (R2), uji t dan uji $f$.

\section{HASIL DAN PEMBAHASAN}

Keseluruhan peningkatan berbagai Penelitian ini mengacu pada hipotesis dan signifikan dari Motivasi Belajar dan Disiplin Belajar Terhadap Prestasi Belajar SMAN 1 Babalan Tahun Pelajaran 2014/2015. Dari hasil analisis uji hipotesis 1 yang digunakan secara parsial menunjukkan bahwa nilai $\mathrm{t}$ hitung = $1,090<\mathrm{t}$ tabel $=1,991$, dengan demikian Ho yang menyatakan tidak ada pengaruh yang positif dan signifikan antara motivasi belajar terhadap prestasi belajar siswa diterima. Sementara dari hasil analisis uji hipotesis 2 yang dilakukan secara parsial menunjukkan bahwa nilai $\mathrm{t}$ hitung $=4,062>\mathrm{t}$ tabel $=1,991$, dengan demikian Ha yang menyatakan ada pengaruh yang positif dan signifikan antara disiplin belajar terhadap prestasi belajar siswa diterima.

Dari analisis uji hipotesis 3 yang dilakukan secara simultan menunjukkan bahwa nilai Fhitung $=15,743>$ Ftabel $=3,12$, dengan demikian Ha yang menyatakan ada pengaruh
NIAGAWAN Vol 8 No 3 November 2019 yang positif dan signifikan antara motivasi belajar dan disiplin belajar secara bersama-sama terhadap prestasi belajar siswa diterima. Berdasarkan uji analisis koefisien determinasi, diperoleh nilai Adjusted R Square sebesar 0,450 atau $45 \%$ dimana hal ini menunjukkan bahwa besarnya sumbangan pengaruh yang diberikan oleh variabel motivasi belajar dan disiplin belajar terhadap prestasi belajar adalah $45 \%$, sedangkan sisanya 55\% dipengaruhi oleh faktorfaktor lain yang tidak dibahas dalam penelitian ini.

\section{KESIMPULAN DAN SARAN}

Dari hasil pengujian dan pembahasan terhadap hasil penelitian yang telah dikumpulkan mengenai motivasi belajar dan disiplin belajar terhadap prestasi belajar ekonomi siswa kelaasXI SMAN 1 Babalan T.A 2014/2015, maka dapat ditarik kesimpulan sebagai yaitu : (1) Berdasarkan hitungan hipotesis secara parsial dari masing-masing variabel motivasi belajar (X1) dan disiplin belajar (X2), disimpulkan bahwa motivasi belajar tidak berpengaruh positif dan signifikan terhadap prestasi belajar siswa. Sedangkan untuk variabel disiplin belajar berpengaruh positif dan signifikan terhadap prestasi belajar siswa, (2) Berdasarkan hasil perhitungan pengaruh keseluruhan/simultan dari variabel motivasi belajar (X1) dan disiplin belajar (X2) terhadap prestasi belajar siswa, disimpulkan ada pengaruh yang positif dan signifikan antara motivasi belajar dan disiplin belajar secara bersama-sama terhadap prestasi belajar siswa, (3) Hasil perhitungan koefisien determinasi menunjukkan bahwa seluruh variabel motivasi belajar (X1) dan disiplin belajar (X2) secara bersama-sama dapat menjelaskan perubahan prestasi belajar siswa (Y) sebesar $45 \%$ sedangkan sisanya $55 \%$ dipengaruhi oleh faktor-faktor lain yang tidak dibahas dalam penelitian ini, (4) Dari kedua variabel antara motivasi belajar dan disiplin belajar faktor yang paling dominan berpengaruh terhadap prestasi belajar siswa di SMAN 1 Babalan T.A 2014/2015 adalah variabel disiplin belajar (X2) karena mempunyai nilai t hitung lebih besar dari thitung variabel motivasi belajar (X1).

Berdasarkan hasil penelitian yang telah diuraikan dan disimpulkan di atas, maka ada beberapa saran yang perlu disampaikan yaitu (1) Hasil penelitian ini dijadikan sebagai pengalaman berharga yang dapat menambah 
ilmu pengetahuan dan wawasan peneliti tentang motivasi belajar dan disiplin belajar siswa khususnya dalam upaya memperoleh prestasi belajar yang baik. Sehingga pada akhirnya peneliti juga dapat menerapkan motivasi dan disiplin pada dirinya dalam pelaksanaan kegiatannya agar memperoleh hasil yang maksimal, (2) Hasil data yang diperoleh menunjukkan bahwa prestasi belajar siswa kelas XI SMAN 1 Babalan hanya berada pada kategori cukup. Untuk meningkatkan prestasi belajar yang optimal, siswa harus dapat membangun motivasi belajar dan meningkatkan disiplin belajarnya, agar lebih dapat memacu untuk melakukan kegiatan belajar lebih maksimal sehingga prestasi belajar yang diperoleh dapat optimal juga, (3) Hasil penelitian ini dapatlah dijadikan sebagai tolak ukur dalam pelaksanaan penelitian selanjutnya, sebagai bahan referensi dan masukan bagi mahasiswa dan peneliti lain yang akan mengadakan penelitian baik sejenis di masa yang akan datang.

\section{REFERENSI}

Arikunto, 2008. Dasar-dasar Evaluasi Pendidikan, Jakarta : Bumi Aksara

Arikunto, Suharsimi, dkk. 2007. Penelitian Tindakan Kelas, Jakarta : Bumi Aksara 2008. Dasar-dasar Evaluasi Pendidikan. Jakarta : Bumi Aksara

Christian searchingines.com/2009/03/10)

Djamarah, S, Zain.2006.Strategi Belajar Mengajar. Jakarta : Rineka Cipta.

Darsono, dkk. 200. Belajar dan Pembelajaran. Semarang : IKIP Semarang Press.

Ibrahim, 2000. Pemelajaran Kooperatif. Jakarta : Grasindo

Khairunnisa. 2008. Penerapan Model Pembelajaran Kooperatif Tipe NHT untuk meningkatkan hasil belajar Ekonomi Siswa Kelas XI SMK Negeri Stabat Tahun Ajaran 2008/2009. Skripsi. FE : Unimed.

Kunandar. 2008. Langkah Mudah Penelitian Tindakan Kelas Sebagai Pengembangan Profesi Guru. Jakarta : Raja Grafindo Persada.

Lie, Anita. 2007. Cooperative Learning, Memperaktekkan Cooperative Learning di Ruang-ruang Kelas. Jakarta : Grasindo.
NIAGAWAN Vol 8 No 3 November 2019 - 2008. Cooperative Learning. Jakarta : Grasindo.

Nurhadi, 2004. Kurikulum 2004 Pertanyaan dan Jawaban. Malang: Grasindo.

Sanjaya, Wina. 2008. Strategi Pembelajaran Berorientasi Standar Pendidikan, Jakarta : Kencana.

Slameto. 2006. Belajar dan Faktor-Faktor yang mempengaruhinya. Jakarta : Rineka Cipta.

Soemarso. 2004. Akuntansi Suatu Pengantar. Jakarta : Salemba Empat.

Soemantri. 2004. Memahami Akuntansi SMK _Seri A. Bandung: Armico.

Sucipto, dkk. 2006. Siklus Akuntansi Perusahaan Jasa_ 1A. Jakarta : Yudistira.

Sudjana, H. 2001. Metode dan Teknik Pembelajaran Partisipatif. Bandung : Falah Production.

Syaiful, Sagala. 2006. Konsep dan Makna Pembelajaran. Bandung : Alfa Beta.

Trianto. 2007. Model-Model Pembelajaran Inovatif Berorientasi Konstruktivistik. Jakarta : Publisher. 